\title{
Phytoprotection
}

\section{Ecology and management of plum curculio, Conotrachelus nenuphar [Coleoptera :Curculionidae], in apple orchards}

\author{
G. Racette, G. Chouinard, C. Vincent et S.B. Hill
}

Volume 73, numéro 3, 1992

URI : https://id.erudit.org/iderudit/706025ar

DOI : https://doi.org/10.7202/706025ar

Aller au sommaire du numéro

Éditeur(s)

Société de protection des plantes du Québec (SPPQ)l

ISSN

0031-9511 (imprimé)

1710-1603 (numérique)

Découvrir la revue

Citer cet article

Racette, G., Chouinard, G., Vincent, C. \& Hill, S. (1992). Ecology and management of plum curculio, Conotrachelus nenuphar [Coleoptera :Curculionidae], in apple orchards. Phytoprotection, 73(3), 85-100. https://doi.org/10.7202/706025ar
Résumé de l'article

Le charançon de la prune (Conotrachelus nénuphar) est un insecte originaire de l'Amérique du Nord. Il s'attaque aux fruits à pépins et à noyaux de l'est des États-Unis et du Canada. Il est un ravageur prépondérant en vergers de pommiers (Maluspumila) au Québec. Au printemps, les adultes se déplacent de leurs sites d'hibernation, localisés principalement dans les boisés, vers les vergers. Avant la nouaison, l'activité de ces insectes est surtout nocturne, mais elle s'étend à toute la journée dès l'apparition des fruits. Les larves quittent le fruit au moment de la chute physiologique, et la pupaison s'effectue dans le sol. La nouvelle génération d'adultes apparaît en août, et se nourrit de fruits jusqu'à l'automne, puis retourne vers les sites d'hibernation. Plusieurs éléments de la bio-écologie du charançon sont méconnus, notamment les relations entre l'insecte et l'hôte, le comportement, la dispersion, le mode de déplacement, la reconnaissance des plantes hôtes et des sites d'hibernation, l'orientation, et les seuils économiques. Il n'existe actuellement aucune méthode fiable pour dépister ce charançon, et aucun moyen biologique de lutte contre ce ravageur. Cependant, des études récentes sur le comportement et l'activité du charançon de la prune en conditions semi-naturelles et naturelles pourraient permettre le développement de stratégies de lutte plus efficaces. Ces travaux sont présentés ici de même qu'une revue des méthodes de lutte (chimique, biologique, génétique, mécanique et culturale) envisageables contre le charançon de la prune. 


\title{
Ecology and management of plum curculio, Conotrachelus nenuphar [Coleoptera: Curculionidae], in apple orchards
}

\author{
Gaétan Racette ${ }^{1,3}$, Gérald Chouinard ${ }^{1,4}$, \\ Charles Vincent ${ }^{2}$, and Stuart B. Hill ${ }^{1}$
}

Received 1991-12-27; accepted 1992-11-10

Plum curculio (Conotrachelus nenuphar) is a native pest of pome and stone fruit in eastern North America. It is a key pest of apple (Malus pumila) orchards in Québec. In spring, adults disperse primarily from woodland overwintering sites to apple orchards. Before fruit set, the beetles are mainly nocturnal. As fruits become available for oviposition, adults extend their activity to the daytime. Full grown larvae found in dropped apples in June (June drop) enter the soil to pupate. The summer brood emerges in August, feeds on the remaining fruit throughout the fall and then disperses to suitable overwintering sites. Little is known of its community and host plant relationships, dispersal behavior, factors influencing its mode of locomotion, choice of food sources, overwintering sites, micro-habitat selection, orientation, and action threshold. Commercially available biocontrol agents are not effective, and convenient and reliable monitoring techniques for the timing of sprays have not been developed. However, recent field and insectary studies on the behavior and activity of plum curculio adults may allow us to improve the efficiency of control strategies. These findings are presented here, together with their implications for control of the plum curculio by modifying its habitat, and by better timing and location of sprays and other interventions. This paper also includes brief reviews of biological controls, insect

growth regulators, and genetic controls for plum curculio.

Racette, G., G. Chouinard, C. Vincent, and S.B. Hill. 1992. Ecology and management of the plum curculio, Conotrachelus nenuphar [Coleoptera: Curculionidae], in apple orchards. PHYTOPROTECTION 73: 85-100.

Le charançon de la prune (Conotrachelus nenuphar) est un insecte originaire de I'Amérique du Nord. Il s'attaque aux fruits à pépins et à noyaux de l'est des ÉtatsUnis et du Canada. II est un ravageur prépondérant en vergers de pommiers (Malus pumila) au Québec. Au printemps, les adultes se déplacent de leurs sites d'hibernation, localisés principalement dans les boisés, vers les vergers. Avant la nouaison, l'activité de ces insectes est surtout nocturne, mais elle s'étend à toute la journée dès l'apparition des fruits. Les larves quittent le fruit au moment de la chute physiologique, et la pupaison s'effectue dans le sol. La nouvelle génération d'adultes apparaît en août, et se nourrit de fruits jusqu'à l'automne,

1. Department of Entomology, Macdonald Campus of McGill University, 21111 Lakeshore Road, Sainte-Anne-de-Bellevue, Québec, Canada H9X 3V9

2. Station de recherches, Agriculture Canada, 430 boul. Gouin, Saint-Jean-sur-Richelieu, Québec, Canada J3B 3E6

3. Current address: Station de recherches, Agriculture Canada, 430 boul. Gouin, Saint-Jean-surRichelieu, Québec, Canada J3B 3E6. Contribution No. 335/92.09.02R

4. Current address: Service de phytotechnie de Saint-Hyacinthe, Ministère de l'Agriculture, des Pêcheries et de l'Alimentation du Québec, 3300, rue Sicotte, Saint-Hyacinthe, Québec, Canada J2S 7B8 
puis retourne vers les sites d'hibernation. Plusieurs éléments de la bio-écologie du charançon sont méconnus, notamment les relations entre l'insecte et l'hôte, le comportement, la dispersion, le mode de déplacement, la reconnaissance des plantes hôtes et des sites d'hibernation, l'orientation, et les seuils économiques. II n'existe actuellement aucune méthode fiable pour dépister ce charançon, et aucun moyen biologique de lutte contre ce ravageur. Cependant, des études récentes sur le comportement et l'activité du charançon de la prune en conditions semi-naturelles et naturelles pourraient permettre le développement de stratégies de lutte plus efficaces. Ces travaux sont présentés ici de même qu'une revue des méthodes de lutte (chimique, biologique, génétique, mécanique et culturale) envisageables contre le charançon de la prune.

\section{INTRODUCTION}

Québec commercial apple (Malus pumila Mill.) orchards harbor a complex entomofauna including 9 key pests, 15 secondary pests and 17 occasional pests (Vincent and Bostanian 1988). Among the key pests is America's native plum curculio (Conotrachelus nenuphar Herbst), which attacks pome and stone fruits throughout most of its geographical range, often ranking first or second in term of potential economic damage if left unchecked (Hoyt et al. 1983). From 1977 to 1989, damage by this insect at harvest was usually below $1 \%$ in Québec commercial apple orchards, whereas damage in unsprayed orchards varied between 6 and 85\% (Vincent and Roy 1992). Within 1-3yr after cessation of pesticide spraying, plum curculio populations invariably return to levels of economic importance (Glass and Lienk 1971; Hagley et al. 1977; Hall 1974). The main control tactic is to apply an insecticide treatment at fruit set, or after the first plum curculio oviposition scar is observed (Prokopy 1985).

Progress in understanding the plum curculio's behavior and ecology has been hampered by its cryptic coloration, nocturnal behavior, thanatosis (Wigglesworth 1953), apparent lack of any pheromone, limited visual and olfactory responses, and the associated lack of adequate monitoring techniques. Consequently, plum curculio has remained the least known of the key North American fruit pest species (Hoyt et al. 1983; Whalon and Croft 1984). In the past decade, however, new information has accumulated concerning the ecology and behavior of the plum curculio. The development of a reliable mar- king technique, using the radioisotope ${ }^{65} \mathrm{Zn}$ (Lafleur et al. 1985) has made possible the study of the behavior of large numbers of adults in the field. The design of improved actographs has enabled us to study adult activity in a field insectary (Racette et al. 1990). Previous behavioral studies relied largely on tree tapping, rearing cages, and visual observations. Lafleur and Hill (1987) and Lafleur et al. (1987) described the plum curculio's spring, fall and within-orchard pattern of dispersal. Chouinard (1991), Chouinard et al.(1992b), Owens etal. (1982), and Racette et al. $(1990,1991)$ described within-tree activity. These significant contributions provide the basis for several new control approaches.

The seminal paper by Quaintance and Jenne (1912) remains an invaluable source of information about the plum curculio's synonymy, distribution, developmental stages, life history, habits, host plants, natural enemies, and control measures. Other key papers include Chapman's (1938) observations of plum curculio in New York apple orchards, and Smith and Flessel's (1968) studies of hibernation and winter mortality, duration of diapause, emergence from hibernation and time of arrival in host trees. Paradis (1956b) and Armstrong (1958) have described the biology of the plum curculio in Québec and Ontario respectively. Holloway (1977) provides a list of papers published between 1911 and 1972. Le Blanc (1982) reviewed the literature up to 1982.

In accordance with Roitberg and Angerilli (1986) we believe that, with a better knowledge of the behavior and ecology of the plum curculio, a reduction in the amount of pesticides used is possible. 
Here we review the literature on the life history, behavior, and ecology of this pest, with particular reference to Québec apple orchards, and discuss how this new information might be used to more effectively control this weevil.

\section{ECOLOGY AND BEHAVIOR}

\section{Winter}

It has been claimed that adult plum curculios overwinter under leaves, grass roots, dried grass, trash, honey suckle growth, pruning piles along ditch banks, near or in orchards, woodlots, brush land, fence rows and stone walls (Bobb 1949; Chapman 1938; Quaintance and Jenne 1912; Whitcomb 1929). Recent detailed studies in Québec, however, have failed to find beetles in most of these locations. Forest with a thick layer of fallen maple (Acer saccharum Marsh) leaves constituted the favorite overwintering site (Lafleur et al. 1987). These sites are characterized by high relative humidity and low air movement. Such conditions minimize the risks of desiccation, particularly in spring (Garman and Zappe 1929; Smith and Flessel 1968). Higher winter mortality is associated with orchard turf (Lafleur et al. 1987), grass litter (Bobb 1949) and bare soil (Smith and Flessel 1968). Winter mortality was $85-96 \%$ in orchard turf compared with $24-58 \%$ in thick litter in an adjacent deciduous forest (Lafleur et al. 1987). McGiffen and Meyer (1986) found that high temperatures induced higher mortality in diapausing adults; $90 \%$ of dead weevils collected in spring were infected by the fungal pathogen Beauveria bassiana (Balsamo) Vuillimen. Lafleur et al. (1987) also found plum curculios infected by Beauveria bassiana in spring in rearing boxes within a deciduous mixed forest. Reproductive diapause is terminated before the end of winter, following prolonged exposure to low temperatures (McGiffen and Meyer 1986; Smith and Flessel 1968). Long days are not required for completion of diapause termination (McGiffen and Meyer 1986). Plum curculios that emerge from hibernation have low fat levels (Smith and Flessel 1968), and must feed on a suitable host for the maturation of their ovaries (Smith and Salkeld 1964).

\section{Spring and summer}

The plum curculio is univoltine north of Virginia and multivoltine (two and sometimes a partial third generation) to the south (Schoene 1936). In southwestern Québec apple orchards, the first adults emerge from hibernation when apples of cv. Mclntosh reach the "green tip" stage (late April), with populations peaking in the trees between mid-May (before tight cluster stage) and early June (10 d after petal fall) (Paradis 1956b). Lafleur and Hill (1987) observed that during that last period, the beetles moved the greatest distance per day. This high rate of movement lasted until late June (June drop). Elsewhere, the highest population densities have been recorded 1-2 wk after petal fall (Chapman 1938; Cox 1951; Garman and Zappe 1929; Quaintance and Jenne 1912; Smith and Flessel 1968; Snapp 1930; Whitcomb 1929). These high population densities last for about $20 \mathrm{~d}$ and then decline rapidly, reaching their lowest levels in early August (Armstrong 1958; Lafleur 1985), when most of the population has pupated in the soil.

Before mid-May, adult plum curculios are inactive or walk slowly within their overwintering sites (Lafleur and Hill 1987). Throughout its geographical range, 3 to 4 d of favorable climatic conditions, including rain (Bobb 1949; Garman and Zappe 1929; Lathrop 1949) and the reaching of certain temperature thresholds (Table 1), trigger spring emergence and dispersal. However, before the tight cluster stage, an increase in mean temperature does not elicit rapid dispersal (Lafleur and Hill 1987). Water loss may inhibit adult dispersal (Smith and Flessel 1968). Although spring emergence may extend over 3-4 wk (Lafleur and Hill 1987), up to $60 \%$ of the population have been observed to emerge on a single day, with males emerging slightly earlier than females (Smith and Flessel 1968). The movement of plum curculios from the ground into host trees is a gradual process, and massive arrival on apple trees on a single day has not been observed. Smith and Flessel (1968) suggested that this prolonged build-up of plum curculio populations in host trees results from a physiological adjustment required to induce dispersal after plum curculio emergence. McGiffen and Meyer (1986) attributed the lag between emer- 
Table 1. Climatic factors related to spring dispersal of the plum curculio

\begin{tabular}{|c|c|c|c|c|}
\hline Factor & Effect & Condition & Region & Reference \\
\hline \multirow{2}{*}{$\begin{array}{l}\text { Mean daily } \\
\text { temperature } \\
\left({ }^{\circ} \mathrm{C}\right)\end{array}$} & $\begin{array}{l}\text { induces spring } \\
\text { emergence }\end{array}$ & between 10.8-15.6 & $\begin{array}{l}\text { Québec } \\
\text { Ontario }\end{array}$ & $\begin{array}{l}\text { Paradis } 1956 \mathrm{~b} \\
\text { Armstrong } 1958\end{array}$ \\
\hline & $\begin{array}{l}\text { induces spring } \\
\text { dispersal }\end{array}$ & $\begin{array}{l}12.8-15.6 \\
\text { for } 3-4 d\end{array}$ & $\begin{array}{l}\text { Arkansas, Georgia, } \\
\text { Maine, Maryland, } \\
\text { Michigan, New York, } \\
\text { Pennsylvania }\end{array}$ & $\begin{array}{l}\text { Quaintance and Jenne 1912; Snapp 1930; } \\
\text { Chapman 1938; Graham 1938; } \\
\text { Lathrop 1949 }\end{array}$ \\
\hline $\begin{array}{l}\text { Maximum } \\
\text { Temperature }\end{array}$ & $\begin{array}{l}\text { induces spring } \\
\text { dispersal }\end{array}$ & 21.1 for $1 \mathrm{~d}$ & $\begin{array}{l}\text { Massachusetts, } \\
\text { New York }\end{array}$ & McGiffen and Meyer 1986 \\
\hline$(\mathcal{C})$ & & $\begin{array}{l}23.9 \text { for } 1 \mathrm{~d} \\
23.9 \text { for } 2-3 \mathrm{~d}\end{array}$ & $\begin{array}{l}\text { Massachusetts } \\
\text { New York }\end{array}$ & $\begin{array}{l}\text { Whitcomb } 1929 \\
\text { Chapman } 1938\end{array}$ \\
\hline $\begin{array}{l}\text { Soil } \\
\text { temperature } \\
\left({ }^{\circ} \mathrm{C}\right)\end{array}$ & $\begin{array}{l}\text { induces spring } \\
\text { emergence }\end{array}$ & $\begin{array}{l}13.3-13.9 \text { at } 2.5 \mathrm{~cm} \\
10 \text { at } 7.6 \mathrm{~cm}\end{array}$ & $\begin{array}{l}\text { Québec } \\
\text { Virginia }\end{array}$ & $\begin{array}{l}\text { Paradis } 1956 \mathrm{~b} \\
\text { Bobb } 1949\end{array}$ \\
\hline $\begin{array}{l}\text { Soil } \\
\text { humidity }\end{array}$ & $\begin{array}{l}\text { increases spring } \\
\text { emergence }\end{array}$ & high & $\begin{array}{l}\text { Connecticut, Maine } \\
\text { Ontario }\end{array}$ & $\begin{array}{l}\text { Lathrop 1949; Garman and Zappe } 1929 \\
\text { Armstrong } 1958\end{array}$ \\
\hline $\begin{array}{l}\text { Atmospheric } \\
\text { saturation } \\
\text { deficit }(\mathrm{mm} \mathrm{Hg})\end{array}$ & $\begin{array}{l}\text { inhibits flight } \\
\text { inhibits spring } \\
\text { dispersal }\end{array}$ & $\begin{array}{l}>17 \\
\text { high }\end{array}$ & $\begin{array}{l}\text { North Carolina } \\
\text { New York }\end{array}$ & $\begin{array}{l}\text { McGiffen and Meyer } 1986 \\
\text { Smith and Flessel } 1968\end{array}$ \\
\hline $\begin{array}{l}\text { Relative } \\
\text { humidity }(\%)\end{array}$ & $\begin{array}{l}\text { induces spring } \\
\text { emergence }\end{array}$ & $>50$ & New York & Smith and Flessel 1968 \\
\hline
\end{tabular}

gence and appearance in host trees either to sampling error associated with tree tapping or to a delay in the occurence of suitable environmental conditions (temperature and vapor pressure deficit) for flight. They concluded that once temperature reached or exceeded the threshold required for adult activity, low vapor pressure deficits would elicit a spring dispersal flight. Chouinard (1991) also found that variations in total activity was related to air saturation deficit. Le Blanc (1982) noted the poor flying ability of plum curculio, and Owens et al. (1982) concluded that plum curculio rarely flies. However, Whitcomb (1929) stated that the plum curculio was a strong flyer and, R. Blanchet (personal communication) intercepted $80 \%$ of dispersing plum curculios on a large screen trap, and only $20 \%$ in gutter pitfall traps, both installed in spring between a forest (overwintering site) and an adjacent apple orchard. Plum curculios landed on the screen as high as $2 \mathrm{~m}$ above ground level. Chouinard (1991) concluded that dropping, crawling and flying are all important means of dispersal.
The mean speed of spring dispersal is characterized by a series of peaks that coincide with the phenological stages of apple trees (Lafleur and Hill 1987). The curculios exhibited their greatest speed of dispersal ( $4.4 \mathrm{~m}$ per d) between 10 and 16 June (fruit set) when 697 degree-days (above a base of $0^{\circ} \mathrm{C}$ ) had been accumulated. High speed of dispersal $(3.3 \mathrm{~m}$ per d) was also observed at the beginning of the fall dispersal period (Lafleur et al. 1987). Lafleur and Hill (1987) concluded that the speed of dispersal before fruit set is influenced by accumulated heat units, but not by small fluctuations in temperature. Variations in daily activity within caged trees also appeared to be related to phenology (Chouinard 1991; Racette et al. 1991).

Upon arrival in the orchard, the adults may congregate in approximately equal numbers of males and females within the ground cover at the base of the fruit trees in the orchard perimeter rows (Chouinard 1991; Lafleur and Hill 1987). Sounds produced by both sexes (IMampe 
and Neunzig 1966) are possibly the cause for these aggregations. The evolutionary significance for this behavior is yet to be determined.

In spring during tree invasion, the adults frequently return to the ground, probably in response to changes in temperature and humidity (Chouinard 1991; Lafleur and Hill 1987; Racette et al. 1991; Smith and Flessel 1968). A study conducted in a southwestern Québec apple orchard revealed that at full bloom, the beetles moved little, but when movements occurred, they happened in late afternoon and at night (Chouinard et al. 1992b; Racette et al. 1991). They moved into the trees during evening when the wind had dropped and the humidity had increased. At petal fall, they were relatively inactive in the day and active at night, even at low temperatures. At that time, Owens et al. (1982) observed that under central Massachussets conditions, plum curculios were active within host trees during the daytime; but no observation was made at night. As the season progressed, they moved into the trees for increasingly longer periods and extended their activity period to daytime (Racette et al. 1990, 1991). Rate of movement was positively related to mean daily air temperature, but some activity persisted at temperatures as low as $1^{\circ} \mathrm{C}$. Owens et al. (1982) also observed that in the evening, the frequency and speed of crawling increased with increasing temperature. Within-tree rate of movement was highest at fruit set when $50 \%$ of the beetles were still active in the morning (Racette et al. 1991), and at that time female plum curculios deposit about an equal number of eggs at night and during the daytime (Crandall 1905; Quaintance and Jenne 1912).

Dispersal within host trees (Racette et al. 1991), and within the orchard, probably occurs in response to foliage development and to the associated within-tree decrease in air movement and increase in humidity. This is probably because plum curculio's need for humid conditions is critical at this time (Garman and Zappe 1929; Smith and Flessel 1968). This is further supported by Lafleur and Hill's (1987) observation that the plum curculio exhibited a preference for early cultivars with dense foliage, even before fruit set. It is also known that air movement within vegetation sometimes inhibits insect activity (Shaw 1982). Furthermore, access to apples, their main food in the trees, may produce physiological changes in the plum curculio that reduce its susceptibility to desiccation (Johnson 1969). Availability of native hosts that bear fruit earlier than commercial apple cultivars may favor any physiological adjustment required for heightened dispersal activity. A few days before June drop, both within-host tree movements and diurnal activity decreased (Lafleur and Hill 1987; Racette et al. 1991).

Plum curculio apparently moves little from tree to tree (Rings 1952; Snapp 1940; Steiner and Worthley 1941). In spring, however, some individuals have been observed to move $146 \mathrm{~m}$ in $10 \mathrm{~d}$ and 205 $\mathrm{m}$ in $40 \mathrm{~d}$ (Rings 1952; Snapp 1940). A quantitative study revealed that $42 \%$ of released beetles (111 of the 264 recaptures) remained on the same standard apple trees over a 65-d period starting at apple bloom (Lafleur and Hill 1987). After their dispersal from overwintering sites, the first plum curculios to arrive at the border row of apple trees were those that subsequently moved furthest within the orchard (Lafleur and Hill 1987). Early cultivars throughout the orchard and young fruits were also preferentially attacked. Beetles have been recovered from trees not bearing fruit (Chapman 1938; Lafleur and Hill 1987; Smith and Flessel 1968). These findings support previous suggestions that plum curculios are more active than was supposed (Calkins et al. 1976; Smith and Flessel 1968), and that most trees within an orchard are subjected to plum curculio exploration (Chapman 1938). After fruit set, dispersal activity decreases gradually, apparently independently of population density (Lafleur and Hill 1987), probably as the need for food and oviposition sites are met. Mating has been observed as plum curculios congregate in the host trees (Smith and Salkeld 1964), in apple blossoms on warm spring days (Le Blanc 1982), and on the ground under the trees (Stuart B. Hill, unpublished data). Adults may copulate three to four times during the oviposition period (Armstrong 1958), which starts at fruit set (late May in Ontario, Armstrong 1958, or early June in Québec, Paradis 1956b) when the fruit is as small as $6 \mathrm{~mm}$ in diameter 
(Garman and Zappe 1929). In Québec, egg laying continues intensively for $3 \mathrm{wk}$ until early July (Paradis 1956b), and then declines abruptly, with relatively few eggs being laid until the termination of oviposition in early August (Armstrong 1958; Paradis 1956b).

Timing of the onset of oviposition is affected by temperature, size and rate of growth of the young apples, and possibly the physiological state of the plum curculio (Lathrop 1949). Oviposition rate is directly related to temperature (Lathrop 1949), but the daily oviposition patterns are apparently unaffected by temperature fluctuation (Owens et al. 1982; Whitcomb 1929). Females lay eggs singly in young apples and cut a distinctive crescentshaped flap that will prevent the emerging larva from being crushed by the rapidly developing apple (Armstrong 1958; Chapman 1938; Quaintance and Jenne 1912). In Québec, Paradis (1956b) found that females lay an average of 73 eggs. Damaged fruit are most abundant in tree rows adjacent to woodlots (Chapman 1938; Garman and Zappe 1929; Le Blanc et al. 1984; Quaintance and Jenne 1912). Towards the center of the orchard, plum curculio damage is usually less severe. Fruit in the upper part of trees tend to be attacked more than those in the lower part (Calkins et al. 1976; Le Blanc et al. 1984), but there is no difference in level of attack with respect to compass direction (Le Blanc et al. 1984).

The egg stage lasts from 3 to $12 \mathrm{~d}$ at mean daily temperatures of 25 to $18^{\circ} \mathrm{C}$ respectively (Paradis 1956b). Larvae spend 15 (Armstong 1958) to $18 \mathrm{~d}$ (Paradis 1956b) in the fruit. Pectic enzymes and cellulase, released by the larvae as they feed on the fruit (Levine and Hall 1978a, 1978b), result in premature dropping of the infested fruit (Whitcomb 1932) before it reaches $3 \mathrm{~cm}$ in diameter (Levine and Hall 1977). This "June drop" occurs at different times in June in the USA (Chapman 1938) and during the last week of June in southern Québec (Paradis 1956b). Larvae in apples that do not fall at this time are usually crushed by the growing fruit tissue (Paradis 1957; Quaintance and Jenne 1912). Apples with egg-laying and feeding scars that remain on the trees become further deformed as they mature. The size and appearance of these scars at fruit maturity vary among cultivars (Chapman 1938). Oviposition damage is economically more important than feeding damage. It is difficult to assess the true impact of plum curculio on "June drop" because this phenomenon overlaps with natural fruit abcission. In heavy crop years, such thinning protects the trees from overbearing (Howard 1906). Larvae eat out irregular cavities in the apple and, in extreme cases, reduce the fruit to a frass-filled shell (Chapman 1938). The fourth instar larva remains in the fallen fruit for a fevv days, makes an exit hole, and then leaves the fruit to burrow into the soil to pupate (Quaintance and Jenne 1912). Emergence of larvae from fallen apples increases after rainfall, at which time temperature has no effect (Lathrop 1949). At other times, heat from direct exposure to the sun may result in larval death within the fallen apples. Emerged larvae move around for 30 to $50 \mathrm{~min}$ as if searching for a suitable place to enter the soil. They pupate at a depth of $1-8 \mathrm{~cm}$ (C)uaintance and Jenne 1912). After 1 mo, starting in July, a new generation of adults emerges, with peak emergence occurring in August in southern Québec (Paradis 1956b). Moisture is required for plum curculios to enter, pupate, and escape from the ground (Chandler 1932). Adult emergence increases after rainfall (Armstrong 1958; Neiswander 1948; Quaintance and Jenne 1912) and also after a few days of high temperatures $\left(26-29^{\circ} \mathrm{C}\right.$ ) (Lathrop 1949). Development from egg to adult takes 50 to $55 \mathrm{~d}$ (Armstrong 1958; Paradis 1956b).

\section{Fall}

Newly emerged adults feed on apples, both on the trees and on the ground, by digging cavities under the skin with their beak. The apple skin around the holes eventually blackens. These feeding cavities may harbor one or more adults. When adults have stored sufficient fat they cease feeding and seek suitable hibernation sites (Smith and Salkeld 1964).

Migration from the orchard to hibernation sites occured from early September to the end of October (Lafleur and Hill 1984; Lafleur et al. 1987). The farthest distance covered during fall dispersal was $142 \mathrm{~m}$ (Lafleur and Hill 1987). The first step in plum curculio dispersal may involve 
orientation towards high tree silhouettes at the edge of an adjacent woodlot, although the predominant direction of movement is not always oriented towards the nearest woodlot or the highest skyline point (Lafleur et al. 1987). This suggests that other factors such as celestial cues (sun, moon, stars) and the magnetic field of the earth may influence adult dispersal (Lafleur et al. 1987). Celestial cues for migration (Wehner 1984), magnetic sensitivity (Gould 1984), and compass sense of orientation (Baker and Mather 1982; Schmidt-Koenig 1979) have been reported as navigational cues in other insect species. Lafleur et al. (1987) considered that wind direction is unlikely to be responsible for the orientation of the adults.

The second step in dispersal, exploratory behavior, occurs at the edge of an adjacent deciduous woodlot. The adults initially moved along the forest edge and, searched for an area with a thick layer of dead leaves about 3-5 m inside the woodlot (Lafleur et al. 1987). When the substrate was unsuitable (e.g., thin deciduous or any thickness of coniferous litter), they returned to the orchard and hibernated in the turf beneath the apple trees (Lafleur et al. 1987). When leaf litter approximates the normal cover in undisturbed deciduous woods or when $1-5 \mathrm{~cm}$ thick of straw is available, the plum curculio remains between the ground and the leaf cover (Armstrong 1958; Lafleur et al. 1987; Smith and Flessel 1968; Snapp 1930). When the litter layer is thin or absent (grass, bare soil) and the adults have nowhere else to overwinter, some penetrate as deep as 5 to $8 \mathrm{~cm}$ into the soil (Armstrong 1958; Bobb 1949; Smith and Flessel 1968). Some adults enter loose soil, even when the litter is thick (Lafleur et al. 1987). Unlike many other beetles, plum curculios are not gregarious in the fall and winter (Lafleur et al. 1987; Smith and Flessel 1968).

\section{MANAGEMENT STRATEGIES}

\section{Monitoring techniques}

The present method of monitoring adult plum curculio in commercial orchards is limited to the examination of several thousand apples at fruit set for evidence of fresh feeding or egg laying scars (Hoyt et al. 1983; LeRoux 1961; Prokopy et al. $1980)$, especially on early cultivars. Recommendations following positive scar identification depend upon previous infestation history and on the characteristics of the surrounding environment (proximity of neglected orchards, natural hosts, potential overwintering sites). However, such scars are only detectable several weeks after the arrival of plum curculio within orchards, and this may be too late to achieve optimal control (Le Blanc et al. 1984). An efficient and reliable monitoring technique or device, and its associated economic threshold, are still lacking. Limb jarring is not popular in integrated pest management (IPM) programs because it can be inaccurate, inconvenient and can cause tree damage. Samples obtained by limb jarring can vary with time of day, time of year (Racette et al. 1990) and skill of the field scout. Among the 15 monitoring devices tested by Le Blanc (1982), Le Blanc et al. (1981), and Radke (1982) none succeeded in catching enough adult beetles to be sufficiently reliable for use in an IPM program. Inspection of 'Granny Smith' apples placed in the trees prior to fruit set for egg laying scars has been used to detect the earliest presence of ovipositing females in the trees by Le Blanc et al. (1984). These apples must be installed in the upper crown level of standard trees, and careful frequent examination is required to detect oviposition scars.

Selection of monitoring sites should take into account that 1) plum curculio attack is greater in the upper level of the trees (Calkins et al. 1977; Le Blanc et al. 1984), 2) early cultivars with dense foliage attract overwintered plum curculios before fruit set (Lafleur and Hill 1987), 3) damage is more severe in tree rows adjacent to woodlots, and 4) before petal fall, plum curculios may occur individually and in clusters on the ground under the rows of apple trees adjacent to woodlots or other overwintering sites. Interception traps, located between an overwintering site and the orchard, might prove effective in catching plum curculio during their spring dispersal.

Although no pheromone has been identified, Alm and Hall (1986a) found that some sensory structures of plum curculio 
antennae are similar to known pheromone receptors in other insects. Consequently, chemical communication between plum curculios and detection of host plants should be investigated further both to elucidate mechanisms involved and help in the development of an effective plum curculio monitoring technique.

\section{Cultural control measures}

Cultural controls encompass an array of techniques that were widely used before the advent of synthetic insecticides. They include habitat management, sanitation, and apple cultivar preference. They can contribute to reducing curculio populations and are an essential component of an effective IPM program. Their importance has been stressed in Hill's (1984, 1990a) approach to ecological pest management through the redesign of agroecosystem and Prokopy et al's (1990) second stage IPM program. Both approaches are heavily dependent on access to a detailed knowledge of the pest's behavior and biology (Chouinard et al. 1992a, b; Lafleur and Hill 1987; Lafleur et al. 1987; Racette et al. 1991).

\section{Habitat management}

New orchards should be established as far as possible from a forest, or isolated from woodlots by plants that are rejected as overwintering sites or in which winter mortality is high (open fields with grass litter or bare soil, or coniferous borders). Established orchards next to forests might be protected by manipulating their borders. Modifications of the habitat to create warmer microclimates with drier conditions might also be detrimental to winter survival of plum curculio, because of its need for conditions of high relative humidity during this period (Garman and Zappe 1929; Lafleur et al. 1987; Smith and Flessel 1968), and because higher temperatures have been found to increase mortality in diapausing adults (McGiffen and Meyer 1986).

An alternative control tactic is to create an overwintering site so favorable that it attracts most of the weevils, which are then killed by application of a pesticide (chemical or biological).

Selective removal of wild hosts (Amelanchier sp., Prunus sp., and Crataegus sp.), and of neglected apple trees and orchards, can greatly reduce fruit damage in commercial orchards (Alm and Hall 1986b; Maier 1990; Prokopy et al. 1990). If early cultivars of exotic fruits and varieties of native host plants are present they can provide females with the food required for ovarian maturation and for the physiological adjustment necessary to survive harsh spring conditions prior to dispersal (Smith and Flessel 1968). Maier (1990) lists 19 exotic and native fruit tree hosts of the plum curculio in the northeastern USA. Habitat management should be performed for a distance of at least $162 \mathrm{~m}$ from the border of the orchard. This was the farthest distance from an orchard recorded for an adult during fall dispersal (Lafleur et al. 1987). This is similar to the $200 \mathrm{~m}$ habitat management zone recommended by Prokopy et al. (1990) for second-stage IPM programs.

\section{Sanitation}

Recommended sanitation measures, such as removing stone walls and stone piles (Bobb 1949; Chapman 1938; Graham 1938), are unlikely to be effective in southern Québec because Lafleur et al. (1987), using labeled beetles, found no plum curculio in either of these locations. Discing deeper than $5 \mathrm{~cm}$, especially under the tree canopy, for several weeks after petal fall has been recommended to kill pupae or expose them to unfavorable weather and natural enemies (Howard 1906; Slingerland and Crosby 1914; Snapp 1923, 1931; Woodside 1935).

Removal of wormy fruit that had fallen onto the ground was once a common control practice for plum curculio (Bethume 1907; Chandler 1940; Chapman 1938; Howard 1906; Quaintance and Jenne 1912; Smith 1948; Snapp 1931; Snapp and Thompson 1931). The fruit was destroyed by burying it (Snapp 1923, 1931; Snapp and Thompson 1931), by dumping it into large bodies of water (Snapp 1923; Snapp and Thompson 1931), by submerging it in boiling water (Snapp 1931), by burning it (Snapp 1923) or by raking it into the sun (Slingerland and Crosby 1914), so that the larvae were killed by excessive heat (Crandall 1905; Quaintance and Jenne 1912). Fallen apples can be collected with modified golf ball picking machines, and destroyed by composting them (Hill 1990b). Ground feeding birds (Quaintan- 
ce and Jenne 1912) and hogs (Petch 1927) have also been used to destroy fallen fruit in unsprayed orchards. Properly pruned trees that allow the sun and wind to penetrate into the canopy could create less favorable conditions for both adult activity (Lafleur and Hill 1987; Racette etal. 1991) and larval development and activity (Slingerland and Crosby 1914).

\section{Apple cultivar preferences}

Early apple cultivars usually have dense foliage and produce flowers and fruit sooner than other cultivars. They are therefore more subjected to plum curculio attack, partly because they provide better cover against natural enemies and adverse climatic conditions, and because they provide food at a critical period when alternative sources are scarce. Many studies reported that the early cv. Melba, which has a particularly dense foliage, harbored a greater number of plum curculio adults in spring than the $\mathrm{cv}$. Mclntosh (Lafleur and Hill 1987; Racette 1988; Whitcomb 1929).

Alm and Hall (1986b) found that most of the crabapple cultivars that are resistant to plum curculio, are also resistant to apple scab, cedar apple rust, powdery mildew and fire blight. The cultivars Ormiston Roy and Donald Wyman suffered less than $4 \%$ damaged fruit at the end of the plum curculio's egg-laying period. Lack of oviposition stimulants, and presence of repellent or antibiotic chemicals may account for the non-preference of these cultivars. Fruit size is unlikely to be an important factor in the resistance mechanism because plum curculios can breed on plants with small fruit such as blueberry (Vaccinium sp.) and wild plum (Prunus sp.) (Alm and Hall 1986b).

The development of late apple cultivars with a sparse foliage, and pruning, designed to provide non-optimal conditions for plum curculio, may be helpful in the planning of comprehensive IPM programs. The use of early apple cultivars and other early flowering alternate hosts as trap trees should also be considered as part of integrated control programs (Hill 1990b).

\section{Mechanical control measures}

Jarring was once used as the main control measure for plum curculio mostly in small orchards in the USA (Chandler 1940;
Chapman 1938; Paradis 1956a; Wylie 1951). No accurate data are available, but Chapman (1938) estimated that jarring can result in a 1 to $36 \%$ decrease in fruit damage. Jarring is time consuming, however, and is not practical for large orchards with standard trees. Furthermore, losses due to fruit falling may occur. In small orchards planted with dwarfor semidwarf rootstocks, it remains a valuable means of control. Racette et al. (1990) found the most productive time for tapping apple tree branches was between 06:00 and 09:00 at petal fall stage. At fruit set, however, the number of captures remained relatively high from 09:00 to 01:00.

\section{Chemical controls}

Insecticides are still the most efficient controls for plum curculio. Since the advent of synthetic chemicals, a number of products have been used against adults, namely nerve poison insecticides and insect growth regulators. Insecticide resistance has not yet been reported in plum curculio.

\section{Insecticides}

Two insecticidal sprays are usually recommended to control the adult plum curculio in the USA. A spray at petal fall ideally is applied within hours of detecting the first oviposition scar of a plum curculio. A second spray (first cover) is applied $10 \mathrm{~d}$ after the latter if substantial rainfall had occured, and $14 \mathrm{~d}$ later if conditions are relatively dry (Prokopy 1985). In Québec apple orchards, the first spray is applied at petal fall (between 30 May and 10 June) and, if necessary, a second spray is applied 7 to $10 \mathrm{~d}$ later (between 10 and 18 June) (Anonymous 1991; Paradis 1956a, 1979).

With careful monitoring of the fruit for oviposition scars, and knowledge of previous location and time of plum curculio's attacks, effective control may be achieved by applying insecticidal sprays only to those parts of orchards that are adjacent to suitable overwintering sites. It may still be necessary, however, to spray the entire orchard once, and apply a supplementary spray along the edges of the orchard, or only where jarring and fruit examination indicate high plum curculio infestation. Recently, border row sprays have been found to be effective in achieving acceptable control (e.g., $<5 \%$ fruit dam- 
age at harvest) of plum curculio in a southern Québec apple orchard (Chouinard et al. 1992a). Because most plum curculios are active at night, and because susceptibility to pesticides increases with the activity of the target species (Saunders 1982), spraying should be done in early evening or at night (Chouinard et al. 1992a; Racette et al. 1990). Susceptibility of plum curculio to pesticides also varies with the compound used (Hall 1979; Neiswander 1948), voltinism, age of the adults (Snapp 1951) and with the time of year (Smith 1954).

The discovery that plum curculio congregates on the ground, under the perimeter rows of trees adjacent to overwintering sites, suggests that control might be achieved by applying insecticides in these areas, and to adjacent wild hosts and neglected orchards (Chouinard et al. 1992a). However, if the product applied is repellent, such as lead arsenate (Quaintance and Jenne 1912; Whitcomb 1932), some insects may avoid treated areas (Gould 1991), and infest the unprotected central zone. To kill individuals that disperse into orchards over several weeks (Lafleur and Hill 1987), the product should have a relatively long residual effect.

Pathogenic micro-organisms (bacteria, fungi, nematodes) should be tested with this "border row treatment approach", because: 1) they can persist longer in their host's cadavers, and would allow for infested insects to act as a reservoir for subsequent contamination, 2) they are not known to be repellent, and 3) would have fewer negative effects on natural enemies, and probably be less detrimental to soil fauna (Lafleur et al. 1987).

Another chemical approach consists of controlling, with organochlorine or organophosphate insecticides applied to the ground, the larvae as they leave the fruit (Stelzer and Fluke 1958). Nowadays, this approach seems promising with biological control agents (Brossard and Hill 1990; Vincent and Bélair 1992). It has yet to be tested for plum curculio in apple orchards.

\section{Insect growth regulators}

Amaytansinoid compounds (mainly trewiasine) from ethanol extracts of Trewia nudiflora (Euphorbiaceae) seeds reduce the number of progeny when plum curcu- lio are fed on treated apples (Freedman et al. 1982). Under laboratory conditions, pupation, egg hatch and larval development are adversely affected by diflubenzuron [1-(4-chlorophenyl)-3-(2,6difluorobenzoyl)urea)] (Calkins etal. 1977), but soil treatments in orchards have been inconclusive.

\section{Genetic control}

Three approaches have been tried in the laboratory. First, Featherson and Hays (1971) crossed diapausing with non-diapausing strains to increase the proportion of non-diapausing individuals. The latter are less likely to survive the winter. In a 6yr study, Smith and Flessel (1968) recorded more than $70 \%$ mortality in a multivoltine strain reared in the laboratory and released in hibernation cages. The rnortality was $100 \%$ in 4 of the 6 yr. Secondly, Padula and Smith (1971) and Stevenson and Smith (1961), by crossing univoltine and multivoltine individuals, were able to cause accelerated degeneration of spermatozoae in the spermathecae, and reduced oviposition and egg hatch. Thirdly, the effect of two chemosterilant alkylating agents (apholate and tepa) on both fecundity and mortality of plum curculio have been tested in the laboratory (Roach and Buxton 1965). Reduced fecundity was the most apparent effect when using a $10 \%$ (by weight) concentration. The number of offspring produced by females were reduced by ca. $90 \%$ as compared to controls. Among many mammalian hormones and related compounds tested for their ability to sterilize female plum curculios, colchicine was the most effective, with no offspring being produced when it was included in the diet at a concentration of $0.02 \%$ (by weight) (Hays and Cochran 1964). Jacklin et al. (1970) reported that 8 krad of ${ }^{60} \mathrm{Co}$ were enough for complete sterilization of males and females, and suggested that the sterile male release technique in the field was justified. Huettel et al. (1976) found, however, that sperm from the latest mating replaced that from a previous mating. Thus, repeated releases of sterile males would be required to maintain sterile mating in wild plum curculio populations. So far, no management program has involved mass release of sterile individuals against the plum curculio. 
Table 2. Most important natural enemies of the plum curculio

\begin{tabular}{|c|c|c|c|c|}
\hline Name & Family & $\begin{array}{l}\text { Stage } \\
\text { attacked }\end{array}$ & Comment & Reference \\
\hline \multicolumn{5}{|l|}{ Parasitoids } \\
\hline Anaphoidea conotracheli Girault & Mymaridae & egg & $\begin{array}{l}\text { widely distributed in } \\
\text { USA }\end{array}$ & $\begin{array}{l}\text { Howard 1906; } \\
\text { Quaintance and Jenne 1912; } \\
\text { Snapp } 1930\end{array}$ \\
\hline Aliolus rufus (Riley) & Braconidae & larva & widely distributed & Armstrong 1958 \\
\hline Aliolus curculionis Fitch & Braconidae & larva & widely distributed & Armstrong 1958 \\
\hline Triapsis kurtogaster Martin & Braconidae & larva & $\begin{array}{l}\text { observed in Québec } \\
\text { only }\end{array}$ & Paradis $1956 \mathrm{~b}$ \\
\hline Microbracon mellitor Say & Braconidae & larva & $\begin{array}{l}\text { recorded in eastern } \\
\text { USA }\end{array}$ & Quaintance and Jenne 1912 \\
\hline Tersiocholus conotracheli (Riley) & Ichneumonidae & larva & widely distributed & $\begin{array}{l}\text { Armstrong 1958; } \\
\text { Quaintance and Jenne } 1912\end{array}$ \\
\hline Myophasia aeneae Wiedemann & Tachinidae & larva & attacks many weevils & $\begin{array}{l}\text { Armstrong 1958; } \\
\text { Quaintance and Jenne } 1912\end{array}$ \\
\hline Cholomyia inaequipes Bigot & Muscidae & larva & attacks many weevils & $\begin{array}{l}\text { Armstrong 1958; } \\
\text { Quaintance and Jenne } 1912\end{array}$ \\
\hline \multicolumn{5}{|l|}{ Predators } \\
\hline Chrysopa spp. & Chrysopidae & larva & many species recorded & Quaintance and Jenne 1912 \\
\hline Garmania bulbicola Owdms. & Phytoseiidae & larva & recorded in New York & Smith 1957 \\
\hline Lycosa gulosa Walckenaer & Lycosidae & adults & recorded in Québec & Lafleur et al. 1987 \\
\hline Bufo americanus americanus Holb. & Bufonidae & adults & recorded in Québec & Chouinard et al. 1991 \\
\hline thrips & Thripidae & egg & one species recorded & Quaintance and Jenne 1912 \\
\hline ground beetles & Carabidae & adult & general insect feeders & $\begin{array}{l}\text { Howard 1906; } \\
\text { Quaintance and Jenne } 1912\end{array}$ \\
\hline ants & Formicidae & larva & & Howard 1906; Snapp 1930 \\
\hline fowls & Phasianidae & $\begin{array}{l}\text { adult } \\
\text { and larva }\end{array}$ & & Quaintance and Jenne 1912 \\
\hline \multicolumn{5}{|l|}{ Pathogens } \\
\hline $\begin{array}{l}\text { Beauveria bassiana (Balsamo) } \\
\text { Vuillimen }\end{array}$ & & adults & $\begin{array}{l}\text { mostly overwintering } \\
\text { adults }\end{array}$ & $\begin{array}{l}\text { Lafleur et al. 1987; } \\
\text { McGiffen and Meyer } 1986\end{array}$ \\
\hline $\begin{array}{l}\text { Bacillus thuringiensis var. } \\
\text { entomocidus } \\
\text { or subtoxicus Heimpel }\end{array}$ & & adults & isolated from adults & Lafleur et al. 1987 \\
\hline
\end{tabular}

\section{Biological control}

Although a number of predators (Chouinard et al. 1992a; Howard 1906; Lafleur et al. 1987; Quaintance and Jenne 1912; Smith 1957; Snapp 1930), parasitoïds (Armstrong 1958; Paradis 1956a; Quaintance and Jenne 1912; Snapp 1930), and pathogens (Brossard and Hill 1990; Lafleur et al. 1987; McGiffen and Meyer 1986) have been identified for plum curculio (Table 2), few of the commercially availa- ble biological control agents (Van Driesche and Carey 1987) have been tested in the field. The fungal pathogens Beauveria bassiana and Metarhizium anisopliae (Metschnikoff) Sorokin caused high levels of mortality in larvae confined in petri dishes and in cups containing soil. Under the same conditions, the nematode Steinernema carpocapsae (=Neoplectana carpocapsae) Weiser was ineffective (Tedders et al. 1982). Many adult plum 
curculios infected with Bacillus thuringiensis Berliner var. subtoxicus and Beauveria bassiana have been collected in the field (Lafleur et al. 1987). Beauveria bassiana is known to be particularly virulent against plum curculio when temperatures exceed $25^{\circ} \mathrm{C}$ (McGiffen and Meyer 1986). Much work is needed to further evaluate the use of these potential pathogenic agents.

In a preliminary study it was found that apple orchards treated with a formulation of Bacillus thuringiensis suffered severely from plum curculio attack (Reissig et al. 1984). Brossard and Hill (1990) conducted laboratory studies to determine whether or not nematodes could kill plum curculio larvae as they enter the soil to pupate. Among Steinernema feltiae (Filipjev), S. carpocapsae (Weiser) and two strains of Heterorhabditis bacteriophora Poinar, the Steinernema spp. appeared to be the most promising for use in commercial orchards. Soil application would also have an impact on apple sawfly larvae, Hoplocampa testudineaKlug (Vincent and Bélair 1992).

\section{CONCLUSION}

Studies of plum curculio movements to and from both apple orchards and overwintering sites, and of its spring and fall behavior within orchards and within trees provide a new basis for the management of this pest. Approaches include manipulation of the environment, selection of less susceptible apple tree cultivars, and better timing and targeting of sprays (Chouinard et al. 1992a). Such management tactics are particularly important in apple orchards because of the relative permanence of such agroecosystems. Further improvements in control programs will depend on gaining an even better understanding of the relationships between environmental conditions and the behavior and ecology of the plum curculio.

In Québec, recent research has focused on strategies to control the plum curculio when it is invading the first border rows of apple trees. Preliminary results using this approach suggest that pesticide use can be dramatically reduced (Chouinard et al. 1992a). Habitat modification will probably play an increasingly important role in the long-term control of recurrent pest problems, including the plum curculio.

As with all control strategies, however, there are costs and benefits such that actions against one pest may influence the amount of damage caused by other pests (Prokopy et al. 1990; Roitberg and Angerilli 1986). The effectiveness of such management approaches is limited by our knowledge of the entire pest system involved.

\section{ACKNOWLEDGMENTS}

Special thanks are extended to Dr. Noubar J. Bostanian, Agriculture Canada Research Station, Saint-Jean-sur-Richelieu, Québec, Canada, for his support during the preparation of this paper and to Carole Brodeur, for typing parts of the manuscript.

\section{REFERENCES}

Alm, S. R., and F. R. Hall. 1986a. Antennal sensory structure of Conotrachelus nenuphar (Coleoptera: Curculionidae). Ann. Entomol. Soc. Am. 79: 324-333.

Alm, S. R., and F. R. Hall. 1986b. Crabapple cultivar preferences of the plum ciurculio Conotrachelus nenuphar (Herbst) (Coleoptera: Curculionidae). Fruit Var. J. 40: 83-87.

Anonymous. 1991. Pommier. Guide des traitements antiparasitaires. Conseil cles productions végétales du Québec. $2 \mathrm{pp}$.

Armstrong, T. 1958. Life history and ecology of the plum curculio, Conotrachelus nenuphar (Herbst) (Coleoptera: Curculionidae) in the Niagara Peninsula, Ontario. Can. Entomol. 90: 8-17.

Baker, R. R., and J. G. Mather. 1982. Magnetic compass sense in the large yellow underwing moth Noctua pronuba L. Anim. Behav. 30: 543-548.

Bethume, C. J. S. 1907. Common insects affecting fruit trees. Ont. Dep. Agric. Bull. 158: 1-47.

Bobb, M. L. 1949. Hibernation of the plum curculio in Virginia. J. Econ. Entomol. 42: 1922.

Brossard, J.-P., and S. B. Hill. 1990. Efficacité de deux espèces d'Heterorhabditis et de Steinernema envers le charançon de la prune, Conotrachelus nenuphar (Herbst) (Coleoptera: Curculionidae). Proc. Pest Man. Soc. Can. 36: 101-104. 
Calkins, C. O., M. D. Huettel, and M. McKoy. 1976. Spatial and temporal distribution of oviposition by plum curculios, Conotrachelus nenuphar. Fla. Entomol. 59: 205-209

Calkins, C. O., A. J. Hill, M. D. Huettel, and E. R. Mitchell. 1977. Effect of diflubenzuron on plum curculio populations in laboratory and field tests. J. Econ. Entomol. 70: 463466.

Chandler, S. C. 1932. A seven year study of the plum curculio in southern Illinois. J. Econ. Entomol. 25: 101-106.

Chandler, S. C. 1940. Control of plum curculio on peach in Illinois. J. Econ. Entomol. 33: 451-453.

Chapman, P. J. 1938. The plum curculio as an apple pest. NY State Agric. Exp. Stn Bull. 684: 1-75.

Chouinard, G. 1991. Spring field activity and foraging behavior of plum curculio, Conotrachelus nenuphar (Herbst), (Coleoptera: Curculionidae), in insecticide treated and untreated Québec apple orchards. Ph.D. thesis, McGill University, Montréal, Québec. 238 pp.

Chouinard, G., S. B. Hill, C. Vincent, and N. N. Barthakur. 1992a. Border row sprays for control of the plum curculio, Conotrachelus nenuphar (Herbst), in apple orchards: a behavioral study. J. Econ. Entomol. 85: 1307-1317.

Chouinard, G., C. Vincent, S. B. Hill, and B. Panneton. 1992b. Cyclic behavior of plum curculio, Conotrachelus nenuphar(Herbst) (Coleoptera: Curculionidae), within caged dwarf apple trees in spring. J. Insect Behav. 5: 385-394

Cox, J. A. 1951. Plum curculio control on prunes. J. Econ. Entomol. 44: 499-504.

Crandall, C. S. 1905. The curculio and the apple. III. Agric. Exp. Stn. Bull. 98: 467-560.

Featherson, N. H., and S. B. Hays. 1971. Diapause in crosses of a laboratory and a wild strain of the plum curculio, Conotrachelus nenuphar. J. Ga. Entomol. Soc. 6: 96-101.

Freedman, B., D. K. Reer, R. G. Powell, R. V. Madriga, and C. R. Smith. 1982. Biological activities of Trewia nudiflora extracts against certain economically important insect pests. J. Chem. Ecol. 8: 409-418.

Garman, P., and M. P. Zappe. 1929. Control studies on the plum curculio in Connecticut apple orchards. Conn. Agric. Exp. Stn. Bull. 301: 373-437.

Glass, E. H., and L. Lienk. 1971. Apple insect and mite populations developing after discontinuance of insecticides: 10 -year record. J. Econ. Entomol. 64: 23-26.

Gould, J. L. 1984. Magnetic field sensitivity in animals. Annu. Rev. Physiol. 46: 585-598.

Gould, F. 1991. Arthropod behavior and the efficacy of plant protectants. Annu. Rev. Entomol. 36: 305-330.
Graham, C. 1938. The plum curculio. Md. Agric. Exp. Stn. Bull. 49: 309-345.

Hagley, E. A. C., L. G. Monteith, D. H. C. Herne, and R. Trottier. 1977. Pest population buildup in apple orchards following omission of insecticide and acaricide sprays. Proc. Entomol. Soc. Ont. 108: 7-11.

Hall, F. R. 1974. Bioeconomics of apple pests: costs appraisal of crop injury data. J. Econ. Entomol. 67: 517-521.

Hall, F. R. 1979. Effects of synthetic pyrethroids on major insect and mite pests of apple. J. Econ. Entomol. 72: 441-446.

Hays, S. B. and J. H. Cochran. 1964. Evaluation of compounds affecting the reproductive potential of the plum curculio. J. Econ. Entomol. 57: 217-219.

Hill, S. B. 1984. Ecological pest control, confronting the causes. Int. J. BioSoc. Res. 5: 14.

Hill, S. B. 1990a. Pest control in sustainable agriculture. Proc. Entomol. Soc. Ont. 121: 5-12.

Hill, S. B. 1990b. Plum curculio, the "hunchback" of the apple orchard. Macdonald J. 51(1): 12-13.

Holloway, R. L. 1977. A bibliography of the plum curculio, Conotrachelus nenuphar (Coleoptera: Curculionidae).S.C.Agric. Exp. Stn. Tech. Bull. 1064: 1-14.

Howard, L. O. 1906. The plum curculio. U. S. Dep. Agric. Bur. Entomol. Circ. 73: 1-10.

Hoyt, S. C., J. R. Leeper, G. C. Brown, and B. A. Croft. 1983. Basic biology and management components for insect IPM. Pages 93-151. in B. A. Croft and S. C. Hoyt (eds.), Integrated management of insect pests of pome and stone fruits. Wiley, New York.

Huettel, M. D., C. O. Calkins, and A. J. Hill. 1976. Allozyme markers in the study of sperm precedence in the plum curculio, Conotrachelus nenuphar. Ann. Entomol. Soc. Am. 69: 465-468.

Jacklin, S. W., E. G. Richardson, and C. E. Younce. 1970. Substerilizing doses of gamma irradiation to produce population suppression in plum curculio. J. Econ. Entomol. 63: 1053-1057.

Johnson, C. G. 1969. Migration and dispersal of insects by flight. Chaucer Press. London. $763 \mathrm{pp}$.

Lafleur, G. 1985. Dispersal and overwintering behavior of plum curculio, Conotrachelus nenuphar (Herbst), (Coleoptera, Curculionidae) in southern Québec. Ph.D. thesis, McGill University, Montréal, Québec. 216 pp.

Lafleur G., and S. B. Hill. 1984. Etude de la dispersion et du comportement du charançon de la prune, Conotrachelus nenuphar (Herbst) (Coleoptera: Curculionidae), à l'aide de traceurs radioactifs au Québec. Pages 25-37 in C. Vincent and N. J. Bostanian (eds.), Bull. Stn. Rech. Saint-Jean-sur-Richelieu. Québec. Volume 19. 
Lafleur, G., and S. B. Hill. 1987. Spring migration, within-orchard dispersal, and apple tree preference of plum curculio (Coleoptera: Curculionidae) in southern Québec. J. Econ. Entomol. 80: 1173-1187.

Lafleur, G., S. B. Hill, and N. N. Barthakur. 1985. Observations on mortality, detection, distance, and rate of loss of label in plum curculio (Coleoptera: Curculionidae), using improved techniques for topical application of radioisotopes on insects. J. Econ. Entomol. 78: 1157-1165.

Lafleur, G., S. B. Hill, and C. Vincent. 1987. Fall migration, hibernation site selection, and associated winter mortality of plum curculio (Coleoptera: Curculionidae) in a Québec apple orchard. J. Econ. Entomol. 80: 11521172.

Lathrop, F. H. 1949. Biology of the plum curculio in Maine. J. Econ. Entomol. 42: 12-18.

Le Blanc, J.-P. R. 1982. Trapping and monitoring techniques for plum curculio, Conotrachelus nenuphar (Herbst), (Coleoptera: Curculionidae), in a southwestern Québec apple orchard. Ph.D. thesis, McGill University, Montréal, Québec. $170 \mathrm{pp}$.

Le Blanc, J.-P. R., S. B. Hill, and R. O. Paradis. 1981. Essais de piégeage du charançon de la prune, Conotrachelus nenuphar (Hbst.) (Coleoptera: Curculionidae) dans une pommeraie du sud-ouest du Québec. Ann. Soc. Entomol. Qué. 26: 182-190.

Le Blanc, J.-P. R., S. B. Hill, and R. O. Paradis. 1984. Oviposition in scout green apples by plum curculio, Conotrachelus nenuphar (Herbst) (Coleoptera: Curculionidae) and its relationship to subsequent damage. Environ. Entomol. 13: 286-291.

LeRoux, E. J. 1961. Variation between samples of fruit, and of fruit damages mainly from insect pests, on apple in Québec. Can. Entomol. 93: 680-694.

Levine, E., and F. R. Hall. 1977. Effect of feeding and oviposition by the plum curculio on apple and plum abcission. J. Econ. Entomol. 76: 603-607.

Levine, E., and F. R. Hall. 1978a. Pectinases and cellulases from plum curculio larvae, possible causes of apple and plum fruit abcission. Entomol. Exp. Appl. 23: 259-268.

Levine, E., and F. R. Hall. 1978b. Physiology of plum fruit abcission induced by larvae of the plum curculio. Hortscience 13: 161.

Maier, C. T. 1990. Native and exotic rosaceous hosts of apple, plum, and quince curculio larvae (Coleoptera: Curculionidae) in the northeastern United States. J. Econ. Entomol. 83: 1326-1332.

Mampe, C.D., andH.H. Neunzig. 1966. Function of the stridulating organs of Conotrachelus nenuphar (Coleoptera: Curculionidae). Ann. Entomol. Soc. Am. 59: 624-615.
McGiffen, M. E., and J. R. Meyer. 1986. Effect of environmental factors on overwintering phenomena and spring migration of the plum curculio, Conotrachelus nenuphar (Coleoptera: Curculionidae). Environ. Entomol. 15: 884-888.

Neiswander, R. B. 1948. Plum curculio on peaches and plums in Ohio. J. Econ. Entomol. 41: 450-453.

Owens, E. D., K. I. Hauschild, G. L. Hubbel, and R. J. Prokopy. 1982. Diurnal behavior of plum curculio (Coleoptera: Curculionidae) adults within host trees in nature. Ann. Entomol. Soc. Am. 75: 357-362.

Padula, A. L., and E. H. Smith. 1971. Reproductive incompatibility between univoltine and multivoltine females of the plum curculio. Ann. Entomol. Soc. Am. 64: 665-668.

Paradis, R. O. 1956a. La lutte contre le charançon de la prune, dans le sud-ouest du Québec. Annu. Rep. Qué. Soc. Prot. Plants 1955. 37: 88-100.

Paradis, R. O. 1956b. Observations sur le cycle évolutif du charançon de la prune, Conotrachelus nenuphar (Hbst.), sur la pomme dans le Québec. Ann. Soc. Entomol. Qué. 2: 60-70.

Paradis, R. O. 1957. Observations sur les dégâts causés par le charançon de la prune, Conotrachelus nenuphar (Hbst.), sur les pommes dans le sud-ouest du Québec. Can. Entomol. 89: 496-502.

Paradis, R. O. 1979. Comment réduire l'emploi des pesticides en vergers de pommiers. Phytoprotection 60: 69-78.

Petch, C. E. 1927. The plum curculio (Conotrachelus nenuphar Herbst) and its control in Québec. Can. Dep. Agric. Circ. 27: 1-4.1.

Prokopy, R. J. 1985. A low-spray apple pest management program for small orchards. Can. Entomol. 117: 581-585.

Prokopy, R. J., W. M. Coli, R. G. Hislop, and K. I. Hauschild. 1980. Integrated management of insect and mite pests in commercial apple orchards in Massachusetts. J. Econ. Entomol. 73: 529-535.

Prokopy, R. J., S. A. Johnson, and M. T. O'Brien. 1990. Second stage integrated management of apple arthropod pests. Entomol. Exp. Appl. 54: 9-19.

Quaintance, A. L., and E. L. Jenne. 1912. The plum curculio. Bull. U. S. Dep. Agric. Bur. Entomol. 103: 1-250.

Racette, G. 1988. Daily activity of plum curculio, Conotrachelus nenuphar (Herbst), (Coleoptera: Curculionidae), and implications for control. M.Sc. thesis., McGill University, Montréal, Québec. 145 pp.

Racette, G., S. B. Hill, and C. Vincent. 1990. Actographs for recording daily activity of plum curculio (Coleoptera: Curculionidae). J. Econ. Entomol. 83: 2386-2392. 
Racette G., G. Chouinard, S. B. Hill, and C. Vincent. 1991. Activity of adult plum curculio (Coleoptera: Curculionidae) on apple trees in spring. J. Econ. Entomol. 84: 18271832.

Radke, S. L. 1982. Dispersal and overwintering of the plum curculio, Conotrachelus nenuphar (Herbst), (Coleoptera: Curculionidae), in southern New Hampshire apple orchards. M.Sc. Thesis, New Hampshire University, Durham. N. H. 43 pp.

Reissig, W. H., R. W. Weires, G. C. Forshey, W. L. Roelofs, R. C. Lamb, and H. S. Aldwinckle. 1984. Insect management in diseaseresitant dwarf and semi-dwarf apple trees. Environ. Entomol. 13: 1201-1207.

Rings, R.W. 1952. Experimental control of plum curculio on peaches. J. Econ. Entomol. 45: 436-444.

Roach, S. H., and J. A. Buxton. 1965. Apholate and tepa as chemosterilants of the plum curculio. J. Econ. Entomol. 58: 802-803.

Roitberg, B. D., and N. P. D. Angerilli. 1986. Management of temperate-zone deciduous fruit pests: applied behavioral ecology. Agric. Zool. Rev. 1: 137-165.

Saunders, D. S. 1982. Insect clocks. Pergamon Press, New York. 409 pp.

Schmidt-Koenig, K. 1979. Directions of migrating monarch butterflies in some parts of the eastern United States. Behav. Processes 4: 73-78.

Schoene, W. J. 1936. Partial second brood of the plum curculio in Virginia. J. Econ. Entomol. 29: 571-573.

Shaw, R. G. 1982. Wind movement within canopies. Pages 17-41 in J.L. Hatfield and I.J. Thomason (eds.), Biometeorology in integrated pest management. Academic Press, New York.

Slingerland, M. V., and C. R. Crosby. 1914. Manual of fruit insects. The MacMillan Compagny, New York. 503 pp.

Smith, C. F. 1948. Plum curculio control in North Carolina. J. Econ. Entomol. 41: 871-879.

Smith, E. H. 1954. Factors influencing the susceptibility of the plum curculio to lead arsenate. J. Econ. Entomol. 47: 871-879.

Smith, E. H. 1957. A method for rearing the plum curculio under laboratory conditions including some biological observations. J. Econ. Entomol. 50: 187-190.

Smith, E. H., and J. K. Flessel. 1968. Hibernation of the plum curculio and its spring migration to host trees. J. Econ. Entomol. 61: 193-203.

Smith, E. H., and E. H. Salkeld. 1964. Ovary development and oviposition rates in the plum curculio, Conotrachelus nenuphar (Coleoptera: Curculionidae). Ann. Entomol. Soc. Am. 57: 781-787.
Snapp, O.I. 1923. Recent developments in plum curculio investigations in Georgia. J. Econ. Entomol. 16: 275-283.

Snapp, O. I. 1930. Life history and habits of the plum curculio in the Georgia peach belts. U.S. Dep. Agric. Tech. Bull. 188: 1-90.

Snapp, O. I. 1931. A preliminary report on the toxic value of fluosilicates and arsenates as tested on the plum curculio. J. Econ. Entomol. 21: 175-178.

Snapp, O. I. 1940. Further studies on the plum curculio in the Georgia peach belt. J. Econ. Entomol. 33: 453-456.

Snapp, O. I. 1951. Plum curculio control with new organic insecticides. J. Econ. Entomol. 50: 457-459.

Snapp, O. I., and J.R. Thompson. 1931. Burying peach drops to prevent the escape of plum curculio adults. J. Econ. Entomol. 24: 559560.

Steiner, H. M., and H. N. Worthley. 1941. The plum curculio problem on peach in Pensylvania. J. Econ. Entomol. 34: 249-255.

Stelzer, L. R., and C. L. Fluke. 1958. Soil insecticides for plum curculio in Wisconsin. J. Econ. Entomol. 51: 131-133.

Stevenson, J. O., and E. H. Smith. 1961. Fecundity and fertility of two strains of the plum curculio, reciprocal crosses and the $F_{1}$ generations. J. Econ. Entomol. 54: 283-284.

Tedders, W. L., D. J. Weaver, E. J. Wehunt, and C. R. Gentry. 1982. Bioassay of Metarhizium anisopliae, Beauveria bassiana and Neoaplectana carpocapse against larvae of the plum curculio, Conotrachelus nenuphar (Herbst) (Coleoptera: Curculionidae). Environ. Entomol. 11: 901-904.

Van Driesche, R., and E. Carey. 1987. Opportunities for increased biological control in Massachusetts. Univ. Mass. Res. Bull. 718, $141 \mathrm{pp}$.

Vincent, C., and G. Bélair. 1992. Biocontrol of the apple sawfly, Hoplocampa testudinea, with entomogenous nematodes. Entomophaga 37: 575-582.

Vincent, C., and N. J. Bostanian. 1988. La protection des vergers de pommiers au Québec: état de la question. Nat. Can. 115: 261-276.

Vincent, C., and M. Roy. 1992. Entomological limits to biological control programs in Québec apple orchards. Acta Phytopathol. Entomol Hung. 27: 649-657

Wehner, R. 1984. Astronavigation in insects. Annu. Rev. Entomol. 29: 277-298.

Whalon, M. E., and B. A. Croft. 1984. Apple IPM implementation in North America. Annu. Rev. Entomol. 29: 435-470.

Whitcomb, W. D. 1929. The plum curculio in apples in Massachusetts. Mass. Agric. Exp. Stn. Bull. 249: 26-52. 
Whitcomb, W. D. 1932. The relation of temperature to the activity and control of the plum curculio in apples. Mass. Agric. Exp. Stn. Bull. 285: 1-16.

Wigglesworth, V. B. 1953. The principles of insect physiology. Methuen \& Co. Ltd. London. $546 \mathrm{pp}$.

Woodside, A. M. 1935. The plum curculio in Virginia. Va. Pol. Inst. Agric. Exp. Stn. 297: 1-20.

Wylie, W.D. 1951. Technique in jarring for plum curculio. J. Econ. Entomol. 44: 818-819. 